\section{Australian Journal of \\ Crop Science}

\title{
Nutrition in tomato (Solanum lycopersicum L) as affected by light: revealing a new role of phytochrome A
}

\author{
Rogério F. Carvalho ${ }^{1}$, Leandro R. Moda ${ }^{2}$, Gilmara P. Silva ${ }^{2}$, Marina A. Gavassi ${ }^{1}$ and Renato M. \\ Prado $^{2 *}$
}

\author{
${ }^{1}$ Department of Biology Applied to Agriculture, São Paulo State University, Via de Acesso Prof. Paulo Donato \\ Castellane s/n, 14884-900, Brazil \\ ${ }^{2}$ Department of Soil and Fertilizer, São Paulo State University, Via de Acesso Prof. Paulo Donato Castellane s/n, \\ 14884-900, Brazil
}

\section{*Correspomnding author: rmprado@fcav.unesp.br}

\begin{abstract}
The far red light insensitive (fri) mutant of tomato, which is phytochrome A (phyA) deficient, displays some characteristics that have recently indicated important functions of this photoreceptor in water relations. With respect to the relationship between nutrition and water relations, we investigated the growth and nutritional status of fri supplied with Hoagland's complete solution and solutions with the individual omission of nitrogen $(\mathrm{N})$, phosphorus $(\mathrm{P})$, potassium $(\mathrm{K})$, calcium $(\mathrm{Ca})$, magnesium $(\mathrm{Mg})$ and sulfur $(\mathrm{S})$. For this purpose, 20-day-old tomato plants of the WT (cv. Moneymaker) and fri mutant were transplanted into pots (one plant per pot) that contained Hoagland and Arnon (1950) solution diluted to 50 per cent in the first week and to 100 per cent from the second week of cultivation until the end of the experiment (50 DAT). Seven treatments were performed: a complete nutrient solution $\left(\mathrm{KH}_{2} \mathrm{PO}_{4}\right.$, $\mathrm{KNO}_{3}, \mathrm{Ca}\left(\mathrm{NO}_{3}\right)_{2} .5 \mathrm{H}_{2} \mathrm{O}, \mathrm{MgSO}_{4} \cdot 7 \mathrm{H}_{2} \mathrm{O}, \mathrm{KCl}, \mathrm{CaCl}_{2}, \mathrm{H}_{3} \mathrm{BO}_{3}, \mathrm{MnCl}_{2} .4 \mathrm{H}_{2} \mathrm{O}, \mathrm{ZnCl}_{2}, \mathrm{CuCl}_{2}, \mathrm{H}_{2} \mathrm{MoO}_{4} \mathrm{H}_{2} \mathrm{O}$ and Fe EDTA) and the individual omission $\mathrm{N}\left(\mathrm{KNO}_{3}, \mathrm{Ca}\left(\mathrm{NO}_{3}\right)_{2} .5 \mathrm{H}_{2} \mathrm{O}\right) ; \mathrm{P}\left(\mathrm{KH}_{2} \mathrm{PO}_{4}\right) ; \mathrm{K}\left(\mathrm{KH}_{2} \mathrm{PO}_{4}, \mathrm{KNO}_{3}\right) ; \mathrm{Ca}\left(\mathrm{CaCl}_{2}\right) ; \mathrm{Mg}$ and S $\left(\mathrm{MgSO}_{4} .7 \mathrm{H}_{2} \mathrm{O}\right)$ from a balanced nutrient solution. The experiment was arranged in a completely randomized factorial design with two genotypes and seven types of nutrient solutions with three replications. Upon harvest, the following measurements were performed: the height of the plants, measured from the base of the stem of each plant to the insertion of the first fully expanded leaf; the stem diameter; the total number of leaves per plant; an indirect chlorophyll measurement, which we called the green color index, and the leaf area. Statistical analysis was performed using analysis of variance (ANOVA) followed by Tukey's test. First, based on growth analyses, fri showed an enhanced dry weight of the shoot, root and whole plant in complete solution compared with the wild type (WT). In addition, the phyA mutant had a multifaceted response compared with that of the WT when the nutrients were omitted. For the fri mutant, the height and green color index were reduced without $\mathrm{N}$ and $\mathrm{K}$; the leaf area without $\mathrm{P}, \mathrm{K}$ and $\mathrm{S}$; the dry weight of the root and shoot without $\mathrm{N}, \mathrm{P}, \mathrm{K}$ and $\mathrm{S}$, and the root, shoot and total plant dry weight without $\mathrm{P}, \mathrm{K}$ and $\mathrm{S}$. On the other hand, the green color index of the fri mutant was enhanced without $\mathrm{Ca}$ and $\mathrm{Mg}$. Together, these results show that in addition to revealing an altered response to nutrition in the fri mutant, phyA can play a role in light signaling in the nutrition and nutritional stress of tomato.
\end{abstract}

Keywords: Tomato; nutrition; abiotic stress; phytochrome; mutant.

Abbreviations: fri_far red light insensitive mutant; DAT_days after transplanting; HY5_LONG HYPOCOTYL 5; WT_wild type.

\section{Introduction}

Phytochromes are a widespread family of red/far-redresponsive photoreceptors that are $\sim 120-\mathrm{kDa}$ peptides (apoproteins) with a covalently linked linear tetrapyrrole bilin chromophore (forming a complex referred to as the holoprotein) (Bae and Choi, 2008). These molecules control a range of physiological responses from seed germination (Dechaine et al., 2009; Oh et al., 2009) to flowering (Andres et al., 2009; Brock et al., 2010) and each year, a considerable number of studies are published describing new biochemical and molecular roles of phytochromes. Many of these discoveries have been identified using genetic tools, mainly plant transgenics and mutants, with Arabidopsis thaliana as the flagship species. In this plant model, many phytochrome signaling components have been identified, revealing how, on what and where phytochromes act (Chen and Chory, 2011). Moreover, phytochrome mutants of economically important species, such as tomato (Solanum lycopersicum), have also permitted the discovery of agronomic traits that appear to be controlled by phytochromes. For example, the hypocotyls of the au tomato mutant, which is phytochrome-deficient (Muramoto et al., 2005), have reduced levels of anthocyanins, which are important antioxidant molecules (Carvalho et al., 2010). Moreover, the leaves of $a u$ exhibited reduced lipid peroxidation and enhanced $\mathrm{H}_{2} \mathrm{O}_{2}$ (Monteiro et al., 2012), generating strong perspectives on the biochemical and molecular manipulation of light signaling. In addition, the far red light insensitive (fri) mutant of tomato (van Tuinen et al., 1995), which is phyA-deficient, produces fruits with important qualities for the paste industry, such as an increased dry weight/fresh weight ratio, total soluble solids, and paste viscosity, and fewer seeds per fruit compared with the wild type (Alba et al., 1999). Curiously, in addition to the improved traits that are displayed by the fri mutant, this genotype rapidly wilts after exposure to high levels of 
evaporation compared with WT plants (Auge et al., 2012). Nevertheless, these authors verified that the stomatal density was not changed, whereas transpiration and stomatal conductance were both lower in the fri than in the WT plants. Moreover, in fri, these results were accompanied by a lower stem-specific hydraulic conductivity, which was associated with a lower xylem vessel number and transversal area, resulting in a reduction in the water supply to the leaves, which rapidly wilted under high evaporative demand. These results indicate that there are many variations in the specific responses of phytochrome A signaling during the transport of water from the roots to the leaves and fruits. Certainly, these issues are related to one of the most important themes in plant science: nutrition. In other words, is the nutritional status affected by phytochrome A? Although phytochrome deficiency in $a u$ can reduce nitrate and nitrite reductase in tomato seedlings (Goud et al., 1994), no nutritional study has been associated with phytochromes. Thus, in the present study, we verified the nutritional status of fri and found a prominent alteration in this genotype during nutrient omission.

\section{Results and Discussion}

Based on altered water relations in the fri tomato mutant (Auge et al., 2012), we hypothesized that this process can interfere with the way in which nutrients are translocated in the plant, which led us to use this genotype to determine a more comprehensive role of phyA in this process. We found a multifaceted response based on the results obtained from the treatments with the complete solution and the omitted nutrients. In fact, compared with the WT, fri had a reduced green color index and leaf area, whereas the root, shoot and whole plant dry weight was higher in this mutant. The $\mathrm{N}, \mathrm{Ca}$ and $\mathrm{Mg}$ contents in the shoots, the $\mathrm{N}, \mathrm{P}, \mathrm{K}, \mathrm{Ca}, \mathrm{Mg}$ and $\mathrm{S}$ contents in the roots and the whole plant $\mathrm{N}, \mathrm{K}, \mathrm{Ca}, \mathrm{Mg}$ and $\mathrm{S}$ contents were enhanced when fri was grown in the complete solution. However, when nutrients were omitted, there were strong changes in the growth and nutritional status, as discussed below.

\section{N deficiency}

Because $\mathrm{N}$ is an essential component of a wide range of molecules, such as proteins, amino acids, and nucleic acids, deficiency of this element most often results in stunted and slow growth as well as leaf chlorosis (Gangwar and Singh, 2011; Thangaradjou et al., 2014). Consequently, our results demonstrate that in both the WT and the fri mutant, N deficiency reduced the height, leaf area, green color index, and root and whole plant dry weight (Table 1). Certainly, these responses can be explained by the reduction in the macronutrient accumulation in the roots, shoots and whole plants triggered by $\mathrm{N}$ deficiency in both genotypes (Table 2 , 3 and 4).

\section{P deficiency}

There was a severe reduction in $\mathrm{P}$ accumulation (78 per cent) in the roots of the phyA mutant subjected to this treatment compared with the complete solution, which indicates that the mutant may have an increased $\mathrm{N}$ requirement associated with an interaction with $\mathrm{P}$. In accordance with this result, the most evident response to $\mathrm{P}$ starvation can be observed in the $\mathrm{N}$ accumulation in the roots of $f r i$, which was reduced to 76 per cent compared with that obtained for the complete solution (a 41 per cent reduction was recorded for the WT) (Table 3). However, the green color index was not reduced under P- deficient conditions, as opposed to $\mathrm{N}$-deficient conditions. Moreover, because phytochromes modulate the accumulation of pigments, such as carotenoids, chlorophylls and anthocyanins (Huq et al., 2004; Carvalho et al., 2010), the reduced green color index in fri grown in the complete solution reveals a predominant role of phyA in pigment accumulation, which is not dependent on $\mathrm{P}$ (Table 1).

\section{K deficiency}

Because $\mathrm{K}$ is an essential nutrient that affects most of the biochemical and physiological processes that influence plant growth and metabolism (Pettigrew, 2008; Wang and $\mathrm{Wu}$, 2013; Hafsi et al., 2014), it was not surprising that $\mathrm{K}$ deficiency resulted in reduced height, leaf area, green color index, and root, shoot and whole plant dry weight of both the WT and fri (Table 1). However, under K deficiency, a more severe reduction in these parameters was observed for fri compared with the WT. This can be associated with a decrease in the $\mathrm{N}$ accumulation in the fri shoots and whole plants, and the $\mathrm{P}$ and $\mathrm{S}$ accumulation in the fri shoot, root and whole plants relative to the levels measured in the WT (Table 2, 3 and 4). Additionally, whether or not the lower K concentrations can further decrease $\mathrm{K}$ absorption as well as plant resistance to drought stress (Wang et al., 2013), it is reasonable to conclude that the high levels of evaporation and reduced water potential in fri that were observed by Auge et al. (2012) are related to the altered K response. However, a more detailed analysis of how this interplay occurs remains to be performed.

\section{Ca deficiency}

When $\mathrm{Ca}$ was omitted, reductions in the height, leaf area, green color index and root, shoot and whole plant dry weight of the WT and fri were observed (Table 1). However, under $\mathrm{Ca}$ deficiency, fri interestingly exhibited a substantially higher (45 per cent) green color index compared with the WT. Phytochromes modulate chlorophyll biosynthesis (Huq et al., 2004), and $\mathrm{Ca}$ mediates phytochrome phototransduction in a wide range of processes, including photosynthesis (Tretyn, 1999; Appenroth and Gabrys, 2003; Eprintsev et al., 2012; Pandey et al., 2013). However, whether there is some inhibitory mechanism through which phy A acts that is associated with $\mathrm{Ca}$ during pigment accumulation remains largely elusive. This complexity can result from a greater accumulation of $\mathrm{P}$ in the shoots (Table 2 ) and $\mathrm{S}$ in all tissues of fri compared with the WT under $\mathrm{Ca}$ deficiency (Table 2, 3 and 4).

\section{Mg deficiency}

$\mathrm{Mg}$ deficiency was directly associated with a lower green color index in the WT. This was expected given that $\mathrm{Mg}$ is a component of the chlorophyll molecule (Williams and Salt, 2009; Hawkesford et al., 2012). However, in this treatment, fri showed similar green color index values as those recorded for the complete solution (Table 1). Although Mg starvation reduced the height, leaf area, and root, shoot and whole plant dry weight of fri and the WT (Table 1), pigment retention in fri does not appear to be associated with $\mathrm{S}$ accumulation because these nutrients were reduced in the mutant compared with the WT (Table 2 and 3). In fact, in the case of S omission, the green color index of fri did not differ from that of the complete solution (Table 1). Mg-chelatase inserts an $\mathrm{Mg}$ ion in an ATP-dependent reaction to produce $\mathrm{Mg}$ protoporphyrin $\mathrm{IX}^{13}$ and ferrochelatase, which synthesizes heme from protoporphyrin IX during chlorophyll biosynth- 
Table 1. Growth analyses and green color index of the WT and fri plants grown under complete or deficient (-) solution.

\begin{tabular}{|c|c|c|c|c|c|c|c|c|c|c|c|c|}
\hline \multirow[b]{3}{*}{$\begin{array}{l}\text { Nutrient } \\
\text { solution }\end{array}$} & \multirow{2}{*}{\multicolumn{2}{|c|}{ Height (cm) }} & \multirow{3}{*}{$\begin{array}{l}\begin{array}{l}\text { Green } \\
\text { index }\end{array} \\
\text { WT }\end{array}$} & \multirow{3}{*}{$\begin{array}{l}\text { color } \\
\text { fri }\end{array}$} & \multirow{2}{*}{\multicolumn{2}{|c|}{ Leaf area $\left(\mathrm{cm}^{2}\right)$}} & \multicolumn{6}{|c|}{ Dry weight (g per plant) } \\
\hline & & & & & & & \multicolumn{2}{|c|}{ Shoots } & \multicolumn{2}{|l|}{ Roots } & \multicolumn{2}{|c|}{ Whole plant } \\
\hline & WT & fri & & & WT & fri & WT & fri & WT & fri & WT & fri \\
\hline Complete & 122.8 & 116.2 & $23.0^{\mathrm{A}}$ & $14.5^{\mathrm{B}}$ & $5146.1^{\mathrm{A}}$ & $3704.7^{B}$ & $27.2^{\mathrm{B}}$ & $36.3^{\mathrm{A}}$ & $1.88^{\mathrm{B}}$ & $4.32^{\mathrm{A}}$ & $29.1^{\mathrm{B}}$ & $40.6^{\mathrm{A}}$ \\
\hline$-\mathrm{N}$ & $29.3^{* \mathrm{~A}}$ & $15.2^{* \mathrm{~B}}$ & $4.9^{*}$ & $3.2^{*}$ & $284.1^{*}$ & $96.7^{*}$ & $1.9^{*}$ & $0.5^{*}$ & $0.42^{*}$ & $0.30^{*}$ & $2.3^{*}$ & $0.7^{*}$ \\
\hline$-\mathrm{P}$ & $62.8^{*}$ & $54.0^{*}$ & $26.0^{\mathrm{A}}$ & $18.3^{\mathrm{B}}$ & $561.8^{*}$ & $461.6^{*}$ & $4.1^{*}$ & $3.0^{*}$ & $1.23^{*}$ & $1.03^{*}$ & $5.4^{*}$ & $4.0^{*}$ \\
\hline$-\mathrm{K}$ & $47.6^{* \mathrm{~A}}$ & $16.7^{* \mathrm{~B}}$ & $36.5^{* \mathrm{~A}}$ & $12.2^{\mathrm{B}}$ & $786.5^{* \mathrm{~A}}$ & $182.4^{* \mathrm{~B}}$ & $4.4^{*}$ & $0.7^{*}$ & $0.58^{* \mathrm{~A}}$ & $0.15^{* \mathrm{~B}}$ & $5.0^{* \mathrm{~A}}$ & $0.8^{* \mathrm{~B}}$ \\
\hline$-\mathrm{Ca}$ & $22.5^{*}$ & $26.0^{*}$ & $15.2^{* \mathrm{~B}}$ & $27.5^{* \mathrm{~A}}$ & $339.5^{*}$ & $674.2^{*}$ & $3.3^{*}$ & $5.0^{*}$ & $0.67^{*}$ & $0.94^{*}$ & $4.0^{*}$ & $6.0^{*}$ \\
\hline$-\mathrm{Mg}$ & $43.83^{*}$ & $24.33^{*}$ & $3.4^{* \mathrm{~B}}$ & $11.9^{\mathrm{A}}$ & $1267.1^{* \mathrm{~A}}$ & $494.2^{* \mathrm{~B}}$ & $5.0^{*}$ & $1.7^{*}$ & $0.22^{*}$ & $0.15^{*}$ & $5.2^{*}$ & $1.9^{*}$ \\
\hline$-S$ & $99.3^{*}$ & $67.7^{*}$ & $13.4^{*}$ & 10.6 & $3327.2^{* A}$ & $1545.7^{* \mathrm{~B}}$ & $28.7^{\mathrm{A}}$ & $11.9^{* \mathrm{~B}}$ & $2.47^{\mathrm{A}}$ & $1.40^{* \mathrm{~B}}$ & $31.2^{\mathrm{A}}$ & $13.3^{* \mathrm{~B}}$ \\
\hline
\end{tabular}

Asterisks within a column indicate a significant difference between the nutritional treatment and the complete solution, and different letters within a row indicate a

significant difference between the genotypes according to Tukey's test at $p<0.05$.

Table 2. Nutrient accumulation (mg per plant) in the shoots of the WT and fri plants grown under complete or deficient (-) nutrient solution.

\begin{tabular}{|c|c|c|c|c|c|c|c|c|c|c|c|c|}
\hline & $\mathrm{N}$ & & $\mathrm{P}$ & & K & & $\mathrm{Ca}$ & & $\mathrm{Mg}$ & & S & \\
\hline $\begin{array}{l}\text { Nutrient } \\
\text { solution }\end{array}$ & WT & fri & WT & fri & WT & fri & WT & fri & WT & fri & WT & fri \\
\hline Complete & $665.7^{\mathrm{B}}$ & $929.1^{\mathrm{A}}$ & 117.7 & 116.2 & 903.5 & 963.3 & $497.0^{\mathrm{B}}$ & $614.0^{\mathrm{A}}$ & $129.3^{\mathrm{B}}$ & $186.6^{\mathrm{A}}$ & 162.5 & 179.0 \\
\hline$-\mathrm{N}$ & $18.5^{*}$ & $4.4^{*}$ & $14.8^{*}$ & $4.0^{*}$ & $42.6^{*}$ & $11.7^{*}$ & $28.7^{*}$ & $9.2^{*}$ & $7.6^{*}$ & $2.7^{*}$ & $11.7^{*}$ & $3.1^{*}$ \\
\hline$-P$ & $114.8^{*}$ & $92.4^{*}$ & $2.9^{*}$ & $2.2^{*}$ & $136.9^{*}$ & $123.2^{*}$ & $64.1^{*}$ & $61.8^{*}$ & $28.3^{*}$ & $31.6^{*}$ & $21.5^{*}$ & $18.4^{*}$ \\
\hline$-\mathrm{K}$ & $203.7^{* \mathrm{~A}}$ & $32.8^{* \mathrm{~B}}$ & $39.1^{* \mathrm{~A}}$ & $7.3^{* \mathrm{~B}}$ & $23.4^{*}$ & $3.1^{*}$ & $66.9^{*}$ & $15.8^{*}$ & $26.2^{*}$ & $5.2^{*}$ & $26.0^{* \mathrm{~A}}$ & $5.4^{* \mathrm{~B}}$ \\
\hline$-\mathrm{Ca}$ & $129.8^{*}$ & $210.7^{*}$ & $35.8^{* \mathrm{~B}}$ & $51.5^{* \mathrm{~A}}$ & $143.6^{*}$ & $231.4^{*}$ & $5.3^{*}$ & $12.8^{*}$ & $33.8^{*}$ & $51.1^{*}$ & $23.8^{*}$ & $35.5^{*}$ \\
\hline$-\mathrm{Mg}$ & $182.7^{*}$ & $66.1^{*}$ & $37.0^{* \mathrm{~A}}$ & $10.6^{* \mathrm{~B}}$ & $260.6^{* A}$ & $95.7^{* \mathrm{~B}}$ & $99.2^{*}$ & $33.6^{*}$ & $3.0^{*}$ & $1.1^{*}$ & $36.9^{* \mathrm{~A}}$ & $12.6^{* \mathrm{~B}}$ \\
\hline$-S$ & $640.2^{\mathrm{A}}$ & $317.9^{* \mathrm{~B}}$ & $129.1^{\mathrm{A}}$ & $52.1^{* \mathrm{~B}}$ & $692.9^{\mathrm{A}}$ & $387.7^{* \mathrm{~B}}$ & $485.5^{\mathrm{A}}$ & $220.7^{* \mathrm{~B}}$ & $150.7^{\mathrm{A}}$ & $51.1^{* \mathrm{~B}}$ & $19.5^{*}$ & $11.8^{*}$ \\
\hline
\end{tabular}

Asterisks within a column indicate a significant difference between the nutritional treatment and the complete solution, and different letters within a row indicate a significant difference between the genotypes according to Tukey's test at $p<0.05$.

Table 3. Nutrient accumulation (mg per plant) in the roots of the WT and fri plants grown under complete or deficient (-) nutrient solution.

\begin{tabular}{|c|c|c|c|c|c|c|c|c|c|c|c|c|}
\hline & $\mathrm{N}$ & & $\mathrm{P}$ & & K & & $\mathrm{Ca}$ & & $\mathrm{Mg}$ & & S & \\
\hline $\begin{array}{l}\text { Nutrient } \\
\text { solution }\end{array}$ & WT & fri & WT & fri & WT & fri & WT & fri & WT & fri & WT & fri \\
\hline Complete & $60.8^{\mathrm{B}}$ & $123.5^{\mathrm{A}}$ & $8.4^{\mathrm{B}}$ & $23.5^{\mathrm{A}}$ & $37.3^{\mathrm{B}}$ & $66.5^{\mathrm{A}}$ & $12.0^{\mathrm{B}}$ & $61.7^{\mathrm{A}}$ & $7.4^{\mathrm{B}}$ & $20.4^{\mathrm{A}}$ & $7.5^{\mathrm{B}}$ & $20.4^{\mathrm{A}}$ \\
\hline$-\mathrm{N}$ & $5.2^{*}$ & $4.3^{*}$ & 6.4 & $5.0^{*}$ & $15.3^{*}$ & $14.1^{*}$ & $1.9^{*}$ & $1.9^{*}$ & $2.0^{*}$ & $1.7^{*}$ & $1.4^{*}$ & $1.3^{*}$ \\
\hline$-P$ & 35.4 & $31.2^{*}$ & $1.2^{*}$ & $1.2^{*}$ & 39.3 & $30.2^{*}$ & $5.3^{*}$ & $6.4^{*}$ & 3.7 & $3.8^{*}$ & $3.8^{*}$ & $3.5^{*}$ \\
\hline$-\mathrm{K}$ & $21.0^{*}$ & $5.8^{*}$ & $5.6^{\mathrm{A}}$ & $1.7^{* \mathrm{~B}}$ & $2.9^{*}$ & $2.4^{*}$ & $4.3^{*}$ & $1.9^{*}$ & $2.8^{*}$ & $0.8^{*}$ & $3.1^{* \mathrm{~A}}$ & $1.0^{* \mathrm{~B}}$ \\
\hline$-\mathrm{Ca}$ & $25.2^{*}$ & $35.2^{*}$ & 6.2 & $7.5^{*}$ & 23.6 & $35.1^{*}$ & $1.4^{*}$ & $1.3^{*}$ & $1.4^{*}$ & $3.4^{*}$ & $2.3^{* \mathrm{~B}}$ & $4.5^{* \mathrm{~A}}$ \\
\hline - Mg & $6.4^{*}$ & $4.8^{*}$ & $1.8^{*}$ & $1.0^{*}$ & $10.7^{*}$ & $5.1^{*}$ & $2.1^{*}$ & $2.1^{*}$ & $0.2^{*}$ & $0.2^{*}$ & $1.3^{*}$ & $0.9^{*}$ \\
\hline$-\mathrm{S}$ & $63.6^{\mathrm{A}}$ & $44.0^{* \mathrm{~B}}$ & 8.4 & $7.2^{*}$ & $73.9^{* A}$ & $52.4^{\mathrm{B}}$ & $16.7^{\mathrm{A}}$ & $11.3^{* \mathrm{~B}}$ & 7.7 & $7.4^{*}$ & $3.2^{*}$ & $2.5^{*}$ \\
\hline
\end{tabular}

Asterisks within a column indicate a significant difference between the nutritional treatment and the complete solution, and different letters within a row indicate a significant difference between the genotypes according to Tukey's test at $p<0.05$.

Table 4. Total (shoot+root) nutrient accumulation (mg per plant) in the WT and fri plants grown under complete or deficient (-) nutrient solution.

\begin{tabular}{|c|c|c|c|c|c|c|c|c|c|c|c|c|}
\hline & $\mathrm{N}$ & & $\mathrm{P}$ & & K & & $\mathrm{Ca}$ & & $\mathrm{Mg}$ & & $S$ & \\
\hline $\begin{array}{l}\text { Nutrient } \\
\text { solution }\end{array}$ & WT & fri & WT & fri & WT & fri & WT & fri & WT & fri & WT & fri \\
\hline Complete & $726.5^{\mathrm{B}}$ & $1052.6^{\mathrm{A}}$ & 126.1 & 139.7 & 940.8 & 1029.8 & $509.1^{\mathrm{B}}$ & $675.7^{\mathrm{A}}$ & $136.7^{\mathrm{B}}$ & $207.0^{\mathrm{A}}$ & $170.1^{\mathrm{B}}$ & $199.4^{\mathrm{A}}$ \\
\hline$-\mathrm{N}$ & $23.7^{*}$ & $8.7^{*}$ & $21.2^{*}$ & $9.1^{*}$ & $57.8^{*}$ & $25.8^{*}$ & $30.7^{*}$ & $11.1^{*}$ & $9.6^{*}$ & $4.4^{*}$ & $13.1^{*}$ & $4.4^{*}$ \\
\hline$-\mathrm{P}$ & $150.2^{*}$ & $123.6^{*}$ & $4.1^{*}$ & $3.4^{*}$ & $176.2^{*}$ & $153.4^{*}$ & $69.3^{*}$ & $68.3^{*}$ & $32.0^{*}$ & $35.4^{*}$ & $25.3^{*}$ & $21.9^{*}$ \\
\hline$-\mathrm{K}$ & $224.7^{* \mathrm{~A}}$ & $38.5^{* \mathrm{~B}}$ & $44.7^{* \mathrm{~A}}$ & $9.0^{* \mathrm{~B}}$ & $26.3^{*}$ & $5.5^{*}$ & $71.2^{*}$ & $17.7^{*}$ & $28.9^{*}$ & $6.0^{*}$ & $29.1^{* \mathrm{~A}}$ & $6.4^{* \mathrm{~B}}$ \\
\hline$-\mathrm{Ca}$ & $155.0^{*}$ & $245.4^{*}$ & $41.9^{* \mathrm{~B}}$ & $59.0^{* \mathrm{~A}}$ & $167.2^{*}$ & $266.5^{*}$ & $6.7^{*}$ & $14.1^{*}$ & $35.2^{*}$ & $54.5^{*}$ & $26.1^{*}$ & $40.0^{*}$ \\
\hline$-\mathrm{Mg}$ & $189.2^{*}$ & $70.9^{*}$ & $38.8^{* \mathrm{~A}}$ & $11.5^{* \mathrm{~B}}$ & $271.3^{* \mathrm{~A}}$ & $100.8^{* \mathrm{~B}}$ & $101.2^{*}$ & $35.7^{*}$ & $3.2^{*}$ & $1.3^{*}$ & $38.2^{* \mathrm{~A}}$ & $13.4^{* \mathrm{~B}}$ \\
\hline$-S$ & $703.8^{\mathrm{A}}$ & $361.9^{* \mathrm{~B}}$ & $137.5^{\mathrm{A}}$ & $59.3^{* \mathrm{~B}}$ & $766.8^{\mathrm{A}}$ & $440.1^{* \mathrm{~B}}$ & $502.2^{\mathrm{A}}$ & $231.9^{* \mathrm{~B}}$ & $158.4^{\mathrm{A}}$ & $58.5^{* \mathrm{~B}}$ & $22.7^{*}$ & $14.3^{*}$ \\
\hline
\end{tabular}

Asterisks within a column indicate a significant difference between the nutritional treatment and the complete solution, and different letters within a row indicate a significant difference between the genotypes according to Tukey's test at $p<0.05$. 
esis, and is under the control of phytochromes in Arabidopsis (Stephenson and Terry, 2008). However, in addition to inferring that phyA is part of the inhibitory signaling of pigments during biosynthesis, the reduced green color index in fri opens a number of new avenues for researching the role of phyA in tomato during this process.

\section{S deficiency}

The green color retention of fri under S starvation was similar to that of the complete solution. However, this mutant had a lower leaf area and root, shoot and whole plant dry weight, as well as a lower accumulation of $\mathrm{N}, \mathrm{P}, \mathrm{K}, \mathrm{Ca}$ and $\mathrm{Mg}$ in the shoots and whole plant compared with the WT (Table 1 and 2). These results provide evidence that fri has an altered nutritional mechanism based on the interaction between phyA and S. In accordance with this, the transcription factor LONG HYPOCOTYL 5 (HY5), which acts downstream of phyA in Arabidopsis (Ang et al., 1998; Ulm et al., 2004), is involved in the regulation of adenosine 5'-phosphosulphate reductase (APR), a key enzyme for sulfate assimilation (Lee et al., 2011; Huseby et al., 2013). Thus, our results reinforce the idea that phyA plays a role in light signaling in $\mathrm{S}$ nutrition, but how this is achieved remains unknown.

\section{Final considerations}

Phytochrome mutants have revealed important roles of photoreceptors from germination to flowering, as well as in abiotic stress responses (Carvalho et al., 2011). Thus, in this work, we demonstrate that a phyA mutant of tomato exhibited varied growth and nutritional status under the omission of $\mathrm{N}, \mathrm{P}, \mathrm{K}, \mathrm{Ca}, \mathrm{Mg}$ and $\mathrm{S}$, indicating that phyA plays a prominent role in the signaling response associated with these elements. Curiously, in the complete solution, fri had higher dry matter as well as $\mathrm{N}, \mathrm{Ca}$ and $\mathrm{Mg}$ in the shoots, $\mathrm{N}, \mathrm{P}, \mathrm{K}, \mathrm{Ca}, \mathrm{Mg}$ and $\mathrm{S}$ in the roots, and $\mathrm{N}, \mathrm{Ca}, \mathrm{Mg}$ and $\mathrm{S}$ in the whole plants compared with the WT. This improved nutritional status in fri could explain the enhanced horticultural traits, such as the dry weight/fresh weight ratio, total soluble solids, and paste viscosity, that were found by Alba et al., (1999). Although it is reasonable to suggest that the altered growth and nutritional status can be associated with modifications of the water relations of $f r i$, such as lower stem-specific hydraulic conductivity, xylem vessel number and transverse area, which lead to a reduction in water supply to the leaves (Auge et al., 2012), new approaches can be used to understand the changes that occur in fri, stimulating intensive research for a better understanding of phyA signaling during water and nutritional stress.

\section{Materials and Methods}

\section{Plant cultivation}

The experiment was conducted in a greenhouse at the Faculdade de Ciências Agrárias e Veterinárias - Unesp, Jaboticabal, São Paulo, Brazil, using tomato (Solanum lycopersicum L.) cv. Moneymaker, which was used as the wild type (WT), as well as the fri mutant. The plants were grown for 49 days (between August and October 2013) in pots containing $8 \mathrm{~L}$ of nutrient solution. The seeds were provided by the "Tomato Genetics Resource Center, Davis, CA, USA" (TGRC).

\section{Experimental Design}

Seven treatments were performed: a complete nutrient solution $\left(\mathrm{KH}_{2} \mathrm{PO}_{4}, \mathrm{KNO}_{3}, \mathrm{Ca}\left(\mathrm{NO}_{3}\right)_{2} .5 \mathrm{H}_{2} \mathrm{O}, \mathrm{MgSO}_{4} \cdot 7 \mathrm{H}_{2} \mathrm{O}\right.$, $\mathrm{KCl}, \quad \mathrm{CaCl}_{2}, \quad \mathrm{H}_{3} \mathrm{BO}_{3}, \quad \mathrm{MnCl}_{2} .4 \mathrm{H}_{2} \mathrm{O}, \quad \mathrm{ZnCl}_{2}, \quad \mathrm{CuCl}_{2}$, $\mathrm{H}_{2} \mathrm{MoO}_{4} \mathrm{H}_{2} \mathrm{O}$ and $\mathrm{Fe}$ EDTA) and the individual omission of $\mathrm{N}\left(\mathrm{KNO}_{3}, \mathrm{Ca}\left(\mathrm{NO}_{3}\right)_{2} .5 \mathrm{H}_{2} \mathrm{O}\right) ; \mathrm{P} \quad\left(\mathrm{KH}_{2} \mathrm{PO}_{4}\right) ; \mathrm{K}\left(\mathrm{KH}_{2} \mathrm{PO}_{4}\right.$, $\left.\mathrm{KNO}_{3}\right) ; \mathrm{Ca}\left(\mathrm{CaCl}_{2}\right) ; \mathrm{Mg}$ and $\mathrm{S}\left(\mathrm{MgSO}_{4} \cdot 7 \mathrm{H}_{2} \mathrm{O}\right)$ from a balanced nutrient solution. The experiment was arranged in a completely randomized factorial design with two genotypes and seven types of nutrient solutions with three replications. In this experiment, 20-day-old WT and fri mutant tomato plants were transplanted into pots (one plant per pot) containing Hoagland and Arnon (1950) solution diluted to 50 per cent in the first week and to 100 per cent from the second week of cultivation until the end of the experiment. The nutrient solutions were prepared with deionized water and replaced every 15 days. The $\mathrm{pH}$ was adjusted twice daily to $5.5 \pm 0.5$ using $\mathrm{NaOH}$ or $\mathrm{HCl} 0.1 \mathrm{M}$. To replace the transpired water, deionized water was used, and the nutrient solution was constantly oxygenated with the aid of one air compressor.

\section{Biochemical, physiological and nutritional analysis}

The plants were harvested 50 days after transplanting (DAT). Upon harvest, the following measurements were performed: the height of the plants, which was measured from the base of the stem of each plant to the insertion of the first fully expanded leaf; the stem diameter; the total number of leaves per plant; an indirect chlorophyll measurement, which we called the green color index, on ten leaves per experimental unit using the OPTI-Sciences ${ }^{\circledR}$ model CCM-200 Hudson, Boston, USA; and the leaf area using an LI-3100C Area Meter Lincoln, Nebraska, USA. The harvested plant material was washed with deionized water, separated into shoots and roots and placed in an oven with forced ventilation at $65{ }^{\circ} \mathrm{C}$ to dry to a constant weight to determine the dry mass. Then, the macronutrient concentration in the dry shoots and roots was determined according to the method described by Bataglia et al. (1983). The dry matter of the shoots increased with the dry matter of the roots, and these values were added to obtain the whole plant dry matter. The nutrient concentration was used to calculate the accumulation of nutrients in the shoots, roots and whole plants.

\section{Statistical analyses}

Statistical analyses were performed using analysis of variance (ANOVA) followed by Tukey's test $(P \leq 0.05)$ using Assistat software (www.assistat.com).

\section{Conclusion}

This work is the first report that addresses the role of phytochromes in plant nutrition. The growth and nutrient data allow us to conclude that in addition to revealing an altered response to nutrition in the fri mutant, phyA can play a role in light signaling in the nutrition and nutritional stress of tomato. However, this is just the beginning because light modulates plant growth through the complex phototoreceptor system that in tomato, in particular, involves phy B1, phy B2, phy $\mathrm{E}$ and phy $\mathrm{F}$. 


\section{Acknowledgements}

The research that led to this article was partially funded by the Brazilian National Research Council (CNPq) under grant 448423/2014-6.

\section{References}

Alba R C, Valenzano J, Kays SJ, Cordonnier MM, Pratt L (1999) Genetic manipulation of phytochromes in tomato (Lycopersicon esculentum Mill.): a novel approach to crop improvement. Acta Hortic. 487: 93-98.

Andres F, Galbraith DW, Talon M, Domingo C (2009) Analysis of PHOTOPERIOD SENSITIVITY5 sheds light on the role of phytochromes in photoperiodic flowering in rice. Plant Physiol. 151: 681-690.

Ang LH, Chattopadhyay S, Wei N, Oyama T, Okada K, Batschauer A, Deng XW (1998) Molecular interaction between COP1 and HY5 defines a regulatory switch for light control of Arabidopsis. Mol Cell. 1: 213-222.

Appenroth KJ, Gabrys H (2003) Ion antagonism between calcium and magnesium in phytochrome-mediated degradation of storage starch in Spirodela polyrhiza. Plant Sci. 165: 12611265.

Auge GA, Rugnone ML, Cortés LE, González CV, Zarlavsky G, Boccalandro HE, Sánchez RA (2012) Phytochrome A increases tolerance to high evaporative demand. Plant Physiol. 146: 228-235.

Bae G, Choi G (2008) Decoding of light signals by plant phytochromes and their interacting proteins. Annu Rev Plant Biol. 59: 281-311.

Bataglia OC, Furlani AMC, Teixeira JPF, Furlani PR, Gallo JR (1983) Método de análises químicas de plantas. IAC. Campinas, São Paulo

Carvalho RF, Quecini V, Peres LEP (2010) Hormonal modulation of photomorphogenesis-controlled anthocyanin accumulation in tomato (Solanum lycopersicum L. cv MicroTom) hypocotyls: Physiological and genetic studies. Plant Sci. 178: 258-264.

Carvalho RF, Campos ML, Azevedo RA (2011) The role of phytochrome in stress tolerance. J Integr Plant Biol. 53: 920929.

Chen M, Chory J: Phytochrome signaling mechanisms and the control of plant development. Trends Cell Biol. 21: 664-671.

Dechaine JM, Gardnerand G, Weinig C (2009) Phytochromes differentially regulate seed germination responses to light quality and temperature cues during seed maturation. Plant Cell Environ. 32: 1297-1309.

Eprintsev AT, Selivanova NV, Fedorin DN, Bashkin SS, Selezneva EA (2012) The role of calcium cations in the mechanism of phytochrome-dependent regulation of the $s d h l$ 2 gene expression and succinate dehydrogenase activity in maize leaves. Biochem (Mosc) Suppl Ser A Membr Cell Biol. 6: 310-313.

Gangwar S, Singh VP (2011) Indole acetic acid differently changes growth and nitrogen metabolism in Pisum sativum L. seedlings under chromium (VI) phytotoxicity: implication of oxidative stress. Sci Hortic. 129: 321-328;

Goud KV, Sharma R (1994) Retention of photoinduction of cytosolic enzymes in aurea mutant oftomato (Lycopersicon esculentum). Plant Physiol. 105: 643-650.

Hafsi C, Debez A, Abdelly C (2014) Potassium deficiency in plants: effects and signaling cascades. Acta Physiol Plant. 36: 1055-1070.
Hawkesford M, Horst W, Kichey T, Lambers H, Schjoerring J, Skrumsager Møller I, White P (2012) Functions of macronutrients. In: Marschner P (ed) Mineral nutrition of higher plants. Springer, New York.

Hoagland DR, Arnon DI (1950) The water-culture method for growing plants without soil. Calif Agric Exp Stn Circ. 347: 132.

Huq E, Al-Sady B, Hudson M, Kim C, Apel K, Quail PH (2004) Phytochrome-interacting factor 1 is a critical bHLH regulator of chlorophyll biosynthesis. Science; 305: $1937-$ 1941.

Huseby S, Koprivova A, Lee BR, Saha S, Mithen R, Wold AB, Bengtsson GB and Kopriva S (2013) Diurnal and light regulation of sulphur assimilation and glucosinolate biosynthesis in Arabidopsis. J Exp Bot. 64: 1039-1048.

Lee BR, Koprivova A, Kopriva X (2011) The key enzyme of sulfate assimilation, adenosine 5'-phosphosulfate reductase, is regulated by HY5 in Arabidopsis. Plant J. 67: 1042-1054.

Monteiro CC, Rolão MB, Franco MR, Peters LP, Cia MC, Capaldi FR, Carvalho RF, Gratão PL, Rossi ML, Martinelli AP, Peres LEP, Azevedo RA (2012) Biochemical and histological characterization of tomato mutants. An Acad Bras Cienc. 84: 573-585.

Muramoto T, Kami C, Kataoka H, Iwata N, Linley PJ, Mukougawa K, Yokota A, Kohchi T (2005) The tomato photomorphogenetic mutant, aurea, is deficient in phytochromobilin synthase for phytochrome chromophore biosynthesis. Plant and Cell Physiol. 46: 661-665.

Oh E, Kang H, Yamaguchi S, Park J, Lee D, Kamiya Y, Choi G (2009) Genome-wide analysis of genes targeted by PHYTOCHROME INTERACTING FACTOR 3-LIKE5 during seed germination in Arabidopsis. Plant Cell. 21: 403419.

Pandey SK, Chandra KK (2013) Impact of integrated nutrient management on tomato yield under farmers field conditions. J Environ Biol. 34: 1047-1051.

Pettigrew WT (2008) Potassium influences on yield and quality production for maize, wheat, soybean and cotton. Physiol Plant. 133: 670-681.

Stephenson PG, Terry MJ (2008) Light signalling pathways regulating the Mg-chelatase branchpoint of chlorophyll synthesis during de-etiolation in Arabidopsis thaliana. Photochem Photobiol Sci. 7: 1243-1252.

Thangaradjou T, Sarangi RK, Shanthi R, Poornima D, Raja K, Saravanakumar A, Balasubramanian ST (2014) Changes in nutrients ratio along the central Bay of Bengal coast and its influence on chlorophyll distribution. J. Environ. Biol., 35, 467-477.

Tretyn A (1999) Calcium-dependent signal transduction pathways in plants-phytochrome mechanism of action as an example. Pol J Pharmacol. 51: 145-151.

Ulm R, Baumann A, Oravecz A, Máté Z, Ádám É, Oakeley EJ, Schäfer E, Nagy F (2004) Genome-wide analysis of gene expression reveals function of the bZIP transcription factor HY5 in the UV-B response of Arabidopsis. Proc Natl Acad Sci USA. 101: 1397-1402.

van Tuinen A, Kerckhoffs LHJ, Nagatani A, Kendrick RE, Koornneef M (1995) Far-red light-insensitive, phytochrome Adeficient mutants of tomato. Mol Gen Genet. 246: 133-141.

Wang M, Zheng Q, Shen Q, Guo S (2013) The critical role of potassium in plant stress response. Int J Mol Sci. 14: 73707390.

Wang Y, Wu WH (2013) Potassium transport and signaling in higher plants. Annu Rev Plant Biol. 64: 451-476.

Williams L, Salt DE (2009) The plant ionome coming into focus. Curr Opin Plant Biol. 12: 247-249. 